\title{
Role of Kayachikitsa an Ayurveda Modality towards the Geriatric Care: A
}

\section{Review}

\author{
Available online at www.hjhs.co.in \\ REVIEW ARTICLE \\ Neeraj Kanungo ${ }^{a}$, Zahida Nagori ${ }^{\mathrm{b}}$, Vijayata Kanungo ${ }^{\mathrm{c}}$ \\ ${ }^{a}$ M.D. Kayachikitsa, Assistant Professor, Kayachikitsa, Government Ashtanga Ayurved College \\ and Hospital, Indore (M.P.) India. \\ ${ }^{\mathrm{b}}$ M.D. Kayachikitsa, Assistant Professor, Panchakarma, Government Ashtanga Ayurved College, \\ and Hospital, Indore (M.P.) India. \\ ${ }^{c}$ M.D. (Panchakarma), Panchakarma Specialist, Indore (M.P.) India.
}

DOI 10.22270/hihs.v4i4.44

\begin{abstract}
The system for the management of health evolved through the history of civilization and Ayurveda is one such oldest system that comprises different branches for specific health purpose, Kayachikitsa is one them. The Kayachikitsa involves general principles and approaches related to the treatment procedure and use of internal medicine. The treatment of body (Kaya) by virtue of Ayurveda medication and principle is general aim of branch Kayachikitsa. The ageing or problems related to old age also need to be care and in this regards Ayurveda mentioned different approaches for geriatric care including use of internal medicine. The use of natural rugs along with general principles of Ayurveda offers health benefits in case of ageing or geriatric health issues. Considering this point here we summarizes an Ayurveda aspect towards geriatric care W.S.R. to Kayachikitsa.
\end{abstract}

Keywords: Ayurveda, Kayachikitsa, Geriatric, Diseases.

\section{Introduction}

Kayachikitsa is branches of Ayurveda that considers various aspects such as; Nidana, Shamana, Shodhana and Satwawajaya for the management of diseases and overall health restoration. The Kayachikitsa not only support towards the maintenance of physical health but also restores mental health status. The approaches of Kayachikitsa such as; medications, counseling and use of detoxification measure, etc. helps to manage good health status.

The aging is biological process that mainly associated with diminish state of Dhatu, Balya and Tridosa. It is believed that Vata Dosa initiate degenerative activity during old age due to which Agni becomes weak, Srotamsi \& Ojabala diminishes and deterioration at Doshic level take places.

Ayurveda Kayachikitsa mentioned different practices towards the potentiating of Agni, Oja and Dhatu thereby balances Doshas at biological level. These all approaches not only help to cure symptoms of early ageing but also boot overall immunity thus prevent from acute infections. Ayurveda drugs such as; Arjuna, Guggulu, Puskarmula, Brahmi, Triphala and Amrita, etc. provides many good health effects that prevent adversity of ageing. Figure 1 depicted approach that cures early ageing.

\section{Kayachikitsa for geriatric care:}

The medicine and other approaches belong from Kayachikitsa modality provides following health benefits that cure ageing:

> The medicine of Kayachikitsa boosts Agni thus enhances metabolic activity in geriatric person.

> The Rasayana drugs potentaite Dhatu thus maintain physical integrity and general appearance.

$>$ The drugs that enhance immunity help to reduce frequency of general 
infections which are very common in elderly.

> The drugs that balances Dosha improves overall physiological functioning of body and prevent prevalence of pathological conditions.

> The detoxifying drugs eliminate waste thus open up channels and normalize excretory process.
> Rasayana drugs impart rejuvenation effects, provide longevity and improve sexual vitality.

> The drugs also help to restore normal circulatory process therefore prevent chances of hypertension and stroke.

$>$ The internal medicine directly pacify Rasa, control obesity, purify Rakta and empower Asthi/joint in elderly person thus prevents common health problems related to ageing. (1-5)

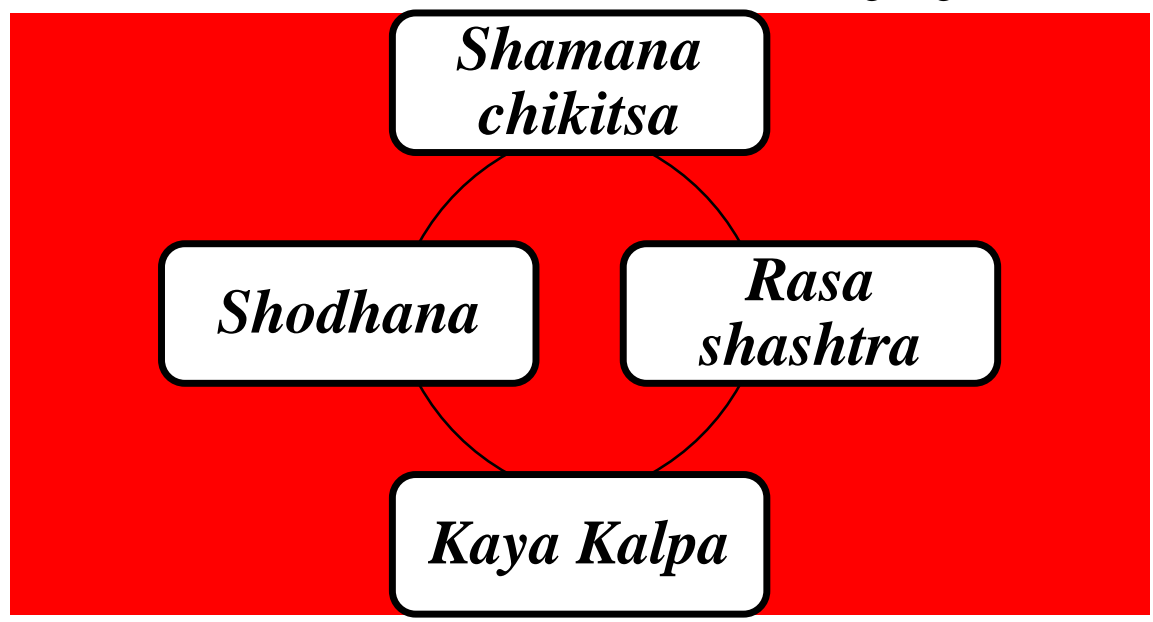

Figure 1. Approaches for geriatric care.

3. The drugs can be used for geriatric care are as follows (5-10):

\section{$>$ Guggulu}

Guggulu reduces fats thus control symptoms of obesity, its anti-inflammatory property suppress joint pain, acts as anti-oxidant and boost circulations.

\section{$>$ Guduchi}

Guduchi in geriatric person can revive skin tissues and enhances immunity thus prevent prevalence of common infections for which elderly are very susceptible.

\section{Amalaki}

Amalaki acts as antioxidants due to the presence of Vitamin-C, helps from age related degeneration and cataract. It boosts digestion and restores circulatory activities.

\section{Ginseng}

Ginseng stimulate skin metabolism thus enhance skin appearances, help form free radicals damage, prevent skin damage induce by pollution and sunlight. It also known to possess sexual stimulant activity.

\section{$>$ Turmeric}

Turmeric exerted good anti-ageing effect, its anti-inflammatory properties relieve pain, its antioxidants action help in oxidative damage and enhances immune power.

\section{> Brahmi}

Brahmi acts as memory enhancer especially in case of age related memory loss, it enhances overall mental activity and refreshes brain.

\section{$>$ Ashwagandha}

Ashwagandha enhances cell regeneration, give rejuvenation, delay signs of ageing and maintain texture of skin.

\section{Gotu-kola}

Gotu kola acts as natural antioxidant due to the flavonoids rich component protect skin from damage and relive symptoms of early ageing.

\section{$>$ Shilajit}


The drug helps in Alzheimer's disease, fatigue, insomnia and treats age related health problems. The constituent of Shilajit; fulvic acid act as an antioxidant thus prevents oxidative damage of tissue. It enhances physical strength, sexual stamina and empowers digestive power.

\section{$>$ Moring}

It is considered as essential source of vitamins and nutrients which enhances skin texture and colour, it helps to look youthful, improves brain activity and boost cardiovascular functioning.

Drugs used for specific purpose in geriatric care are as follows:

Drugs improve skin luster and complexion : Bhringaraja and Somaraji

Drugs improve Drishti (Vision)

Drugs improve Shukra (sexual strength)

Drugs used for cardio functioning and heart : $A$

Drugs used for hearing improvement

Drugs for respiratory care

Drugs for digestive system

Drugs cure nervous system

Drugs boost excretory system in elderly

\section{Conclusion}

The complete management of health/body comes under approaches of Kaya Chikitsa that mainly involves diagnosis and treatment of health ailments using medicine and other modalities. These therapies help to maintain balance of Vata, Pitta and Kapha, potentiate Dhatu, enhance nourishment, regularize circulatory process and detoxify body thus prevent disease prevalence and also combat against adverse effects of degenerative ageing. Ayurveda imparts longevity thus offers great response in geriatric care. Kaya Chikitsa involves uses of various internal medicines for the management of ageing or geriatric care. Ashwagandha, Musali, Arjuna, Haritaki, Shankhapushpi, Vidanga, Shilajit, Ginseng and Turmeric, etc. are some drugs that helps in age related health problems. The drugs and other approaches of Kaya Chikitsa improve skin luster, Drisht, Shukra, cardio functioning, metabolic activities, functioning of nervous system and regularizes excretory system in elderly person. Finally it can be concluded that ayurveda medicine can be used as an alternative approach for geriatric care without any adverse effects.

\section{Acknowledgements}

\section{: Saptamrta lauha and Kataka}

: Ashwagandha, Kapikacchu bija and Musali

: Dashamula Taila and Apamarga Taila

: Vardhaman pippli

: Long pepper \& Haritaki

: Calamus \& Shankhapushpi

\section{Vidanga and Punarnava}

I would like to express my gratitude to Himalayan Journal of Health Sciences who gave me the opportunity to publish the article.

Financial Disclosure statement: The author received no specific funding for this work.

\section{Conflict of Interest}

The author declares that there is no conflict of interest regarding the publication of this article.

\section{References}

1. Sharma PV. Sushruta samhita, part 1, su /su/1/3. Varanasi: Chaukhamba Bharati Academy; 1999.p.1

2. Ayurveda and Siddha for geriatric care (Rasayana therapies-Background papers). New Delhi: CCRAS

3. Vaidya Jadavji Trikamji Acharya and Narayan Ram Acharya; Sushruta samhita of sushruta with Nibandhasangraha commentary of Sri Dalhanacharya. su /su/17/4-10, 17, 18. Varanasi: Chaukhamba Sanskrit sansthan; 2015.p. 82-83

4. Dwivedi KK. and Singh RH. A study on geriatric patients and response of Ashwagandha as anti-aging agent. Ph.D. Thesis Kayachikitsa, Banaras Hindu University; 1997

5. Vaidya Jadavji Trikamji Acharya and Narayan Ram Acharya, Sushruta samhita of sushruta with Nibandhasangraha commentary of Sri Dalhan Acharya. su /ni/5/5-13, 20-28, 33, 34. Varanasi: Chaukhamba Sanskrit sansthan; 2015.p. 284-86

6. Singh RH. Strength of Ayurveda in Geriatric Health Care. Keynote lecture delivered at State launching of National Campaign on Geriatric Health Care 
through Ayurveda. New Delhi: Dept. of AYUSH, Govt. of India; 2008

7. Babu S. Geriatrics in Ayurveda, chapter III, Chaukamba Orientalia. reprint edition. Varanasi; 2013.p. 16

8. Shastri AD. Sushruta samhita of maharsi sushruta, part 1. su /sha/6/3- 13, 25-31, 33-44. Varanasi: Chaukhamba Sanskrit sansthan; 2013.p.71-74
9. Srikantha murthy KR. Sarangadhara samhita by Sarangadhara. Seventh edition. Varanasi: Chaukhambha orientalia; 2007.p. 266-67.

10. Sushruta, SushrutaSamhita with Nibandha Sangrha Commentary of Dalhanacarya, Sutrasthan 35 verse 29. edited by Vidya Yadavji Trikarmaji Acharya. 7th Edition. Varanasi: Chaukambha Surbharti Prakashan; 2008.p. 155. 